\title{
Korelasi Kadar Feritin dengan Jumlah CD4, CD8, dan Rasio CD4/CD8 pada Penyandang Talasemia Mayor Anak
}

\author{
Bonnie Arseno, Djatnika Setiabudi, Susi Susanah \\ Bagian Ilmu Kesehatan Anak Fakultas Kedokteran Universitas Padjadjaran/ Dr. Hasan Sadikin, Bandung
}

\begin{abstract}
Latar belakang. Pada talasemia mayor, peningkatan penyerapan besi dan transfusi darah regular mengakibatkan penumpukan besi pada berbagai organ dan gangguan sistem imun melalui berbagai mekanisme. Keadaan ini berkaitan dengan risiko infeksi pada penyandang talasemia mayor anak.

Tujuan. Untuk menganalisis korelasi kadar feritin dengan jumlah CD4, CD8, dan rasio CD4/CD8 pada penyandang talasemia mayor anak.

Metode. Penelitian observasional analitik menggunakan rancangan potong lintang, subjek 30 anak yang memenuhi kriteria penelitian. Analisis data menggunakan uji korelasi.

Hasil. Didapatkan jumlah CD4 absolut, CD4\%, CD8 absolut dan rasio CD4/CD8 menurun. Selain itu, terdapat jumlah CD4 absolut, CD8 absolut dan CD8\% meningkat. Pada kelompok usia $\leq 5$ tahun, korelasi kadar feritin dengan CD8 absolut, CD8\%, dan rasio CD4/CD8 berturut-turut menghasilkan koefisien korelasi 0,691, 0,557, -0,680, dan p<0,05. Sementara pada kelompok lama terapi $\leq 5$ tahun korelasi kadar feritin dengan CD8 absolut, CD8\%, dan rasio CD4/CD8 menghasilkan koefisien korelasi 0,709, $0,571,-0,726$ dengan $\mathrm{p}<0,05$.

Kesimpulan. Tidak terdapat korelasi antara kadar feritin dengan jumlah CD4, CD8, rasio CD4/CD8. Peningkatan kadar feritin akan diikuti dengan peningkatan jumlah CD8 absolut dan CD8\%, serta penurunan rasio CD4/CD8 pada penyandang talasemia mayor anak berdasar atas usia dan lama terapi $\leq 5$ tahun. Sari Pediatri 2017;19(2):76-80
\end{abstract}

Kata kunci: CD4, CD8, feritin, rasio CD4/CD8, subset limfosit T, talasemia mayor anak

\section{The Correlation of Ferritin Levels with CD4, CD8, and CD4/CD8 Ratio in Children With Thalassemia Major}

Bonnie Arseno, Djatnika Setiabudi, Susi Susanah

Background. Increased iron absorption and regular blood transfusions in children with thalassemia major cause iron overload and further causing iron deposit on organs and lead disruption of immune system through a variety of mechanisms. This condition will be related to the risk of infection in children with thalassemia major

Objective. To analyze the correlation of ferritin levels with CD4, CD8, and CD4/CD8 ratio in children with thalassemia major.

Methods. This is an analytic observational and cross-sectional study in children with thalassemia major. Thirty children met the criteria of the study. Analysis of the data using correlation test.

Results. Absolute CD4 count, CD4\%, absolute, CD8 and CD4/CD8 ratio decrease, but there are increased in absolute CD4, CD8, and CD $8 \%$ absolute. In $\leq 5$ years old age group, the correlation of ferritin levels with absolute CD8, CD8\%, and the ratio of CD4/ CD8 resulted respectively in a correlation coefficient $0.691,0.557,-0.680$, and $p<0.05$. In $\leq 5$ years old duration of therapy group, the correlation of ferritin levels with absolute CD8, CD8\%, and the ratio of CD4/CD8 resulted in a correlation coefficient 0.709 , $0.571,-0.726, \mathrm{p}<0.05$.

Conclusions. There is no correlation between the levels of ferritin with CD4 cell count, CD8, CD4 / CD8 ratio. But in this study we found that increased ferritin levels will be followed by an increasing number of absolute CD8 and CD8\%, and a decrease in CD4 / CD8 ratio in children with thalassemia major by age group and duration of therapy $\leq 5$ years. Sari Pediatri 2017;19(2):76-80

Keywords: CD4, CD8, ferritin, CD4/CD8 ratio, T lymphocyte subsets, children with thalassemia major

Alamat korespondensi: Dr. Bonnie Arseno. Bagian Ilmu Kesehatan Anak Fakultas Kedokteran Universitas Padjadjaran/ Dr. Hasan Sadikin Bandung.. E-mail: bonniears@gmail.com 
T alasemia merupakan penyakit kelainan gen tunggal terbanyak, diturunkan secara autosomal resesif yang saat ini sudah menjadi masalah kesehatan dunia. ${ }^{1}$ Diperkirakan $1,5 \%$ populasi dunia (80-90 juta orang) merupakan pembawa sifat talasemia dan 60.000 anak lahir sebagai penyandang talasemia dan insiden terbanyak terjadi di negara berkembang. ${ }^{1-3} \mathrm{Di}$ Indonesia, 6-10 dari setiap 100 orang membawa gen penyakit ini. Jumlah seluruh penyandang talasemia di Indonesia saat ini 9.900 orang. Talasemia mayor terjadi karena berkurang atau tidak adanya sintesis rantai globin yang menyebabkan peningkatan destruksi eritrosit berat sehingga menyebabkan anemia dan peningkatan penyerapan besi tubuh. ${ }^{3,4}$ Keadaan ini mengakibatkan penyandang talasemia mayor akan memerlukan transfusi darah sepanjang hidupnya/transfusion dependent thalassaemia (TDT). ${ }^{3,4}$

Peningkatan penyerapan besi dan transfusi darah menyebabkan kelebihan besi yang disimpan sebagai feritin dan mengakibatkan penumpukan besi pada berbagai macam organ dan lebih jauh dapat menyebabkan gangguan sistem imun melalui berbagai mekanisme. Gangguan sistem imun yang terjadi adalah pengurangan fagositosis oleh neutrofil, pengurangan opsonisasi, penurunan jumlah CD4 dan rasio $\mathrm{CD} 4 / \mathrm{CD} 8$, peningkatan jumlah $\mathrm{CD} 8$, gangguan sekresi imunoglobulin, serta supresi fungsi sistem komplemen. Hal ini berkaitan dengan risiko infeksi yang merupakan penyebab kematian kedua tersering setelah gagal jantung..$^{5-16}$ Jumlah CD4, CD8, serta rasio CD4/CD 8 berbeda menurut kelompok usia, ras, dan etnis. ${ }^{17-19}$ Selain itu, dalam perkembangannya terjadi perubahan jumlah CD4, CD8, serta rasio CD4/CD8. Usia lebih dari 5 tahun mulai terjadi penurunan jumlah CD4, peningkatan CD8, dan penurunan rasio CD4/ CD8. ${ }^{17-19}$ Penelitian sebelumnya mengenai korelasi feritin dengan jumlah subset limfosit T mendapatkan hasil bervariasi. ${ }^{5,9,15,16,20-23}$ Penelitian ini bertujuan menganalisis korelasi kadar feritin dengan jumlah CD4, CD8, dan rasio CD4/CD8 pada penyandang talasemia mayor anak.

\section{Metode}

Penelitian observasional analitik menggunakan rancangan potong lintang. Kriteria inklusi adalah penyandang talasemia mayor anak bergantung pada transfusi, mendapat terapi kelasi besi. Kriteria eksklusi adalah penyandang talasemia mayor anak yang telah displenektomi, sedang mengalami infeksi, penyandang talasemia mayor anak yang diketahui menderita penyakit imunodefisiensi primer atau penyandang talasemia mayor anak penderita HIV. Perhitungan ukuran sampel digunakan rumus penentuan ukuran sampel untuk penelitian analisis korelatif dengan kesalahan tipe 1 ditetapkan sebesar 5\%, dengan hipotesis dua arah sehingga didapatkan ukuran sampel minimal 30 subjek.

Variabel bebas pada penelitian ini adalah kadar feritin serum, sementara variabel bergantung adalah jumlah CD4, CD8, dan rasio CD4/CD8. Penelitian dilaksanakan sejak Februari 2017 sampai dengan Maret 2017 di Klinik Hematologi-Onkologi Departemen/ SMF Ilmu Kesehatan Anak RSHS/FKUP setelah mendapat persetujuan Komite Etik Penelitian Kesehatan Fakultas Kedokteran Universitas Padjadjaran/ RSUP Dr. Hasan Sadikin Bandung. Penelitian ini dilaksanakan dengan dana mandiri. Setelah dilakukan pendataan, diperoleh informed consent dari orangtua subjek dengan ditandatanganinya lembar persetujuan ikut dalam penelitian. Kemudian, dilakukan anamnesis, pemeriksaan fisis, dan pemeriksaan laboratorium terhadap subjek penelitian tersebut. Pemeriksaan jumlah CD4, CD8, dan rasio CD4/CD8 dilakukan di laboratorium Prodia Bandung.

Analisis data menggunakan komputer program SPSS versi 21.0 for windows. Analisis statistik untuk data numerik, sebelum dilakukan uji statistik data numerik tersebut dinilai dengan menggunakan uji Shapiro Wilks. Analisis statistik variabel numerik menggunakan uji korelasi Pearson dan alternatif uji Spearman. Interpretasi hasil uji hipotesis berdasarkan kekuatan korelasi berdasar atas kriteria Guillford, arah korelasi, dan kriteria kemaknaan yang digunakan adalah nilai $\mathrm{p} \leq 0,05$ artinya secara statistik bermakna.

\section{Hasil}

Selama kurun waktu penelitian pengumpulan subjek dilakukan secara konsekutif. Karakteristik umum subjek penelitian tertera pada Tabel 1 .

Tabel 2. menunjukkan bahwa tidak terdapat korelasi kadar feritin serum dengan jumlah CD4 
Tabel 1. Karakteristik subjek penelitian

\begin{tabular}{|c|c|}
\hline Variabel & $\mathrm{n}=30$ \\
\hline \multicolumn{2}{|l|}{ Usia (tahun) } \\
\hline Median (kisaran) & $6(4-13)$ \\
\hline \multicolumn{2}{|l|}{ Usia, (tahun), $\mathrm{n}$} \\
\hline$\leq 5$ & 11 \\
\hline$>5$ & 19 \\
\hline \multicolumn{2}{|l|}{ Jenis kelamin, $\mathrm{n}$} \\
\hline Laki-laki & 15 \\
\hline Perempuan & 15 \\
\hline \multicolumn{2}{|l|}{ Status gizi, $\mathrm{n}$} \\
\hline Lebih & 0 \\
\hline Baik & 25 \\
\hline Kurang & 5 \\
\hline \multicolumn{2}{|c|}{ Lama terapi, (tahun), n } \\
\hline$\leq 5$ & 13 \\
\hline$>5$ & 17 \\
\hline \multicolumn{2}{|l|}{ Interval transfusi, $\mathrm{n}$} \\
\hline 2 minggu & 3 \\
\hline 3 minggu & 3 \\
\hline 4 minggu & 24 \\
\hline \multicolumn{2}{|l|}{ Jenis kelasi besi, $\mathrm{n}$} \\
\hline Deferipron & 27 \\
\hline Deferasiroks & 3 \\
\hline \multicolumn{2}{|c|}{ Kepatuhan konsumsi kelasi besi, $\mathrm{n}$} \\
\hline Optimal & 21 \\
\hline Tidak optimal & 9 \\
\hline \multicolumn{2}{|l|}{ SGOT, } \\
\hline Rerata \pm (kisaran) & $49(21-101)$ \\
\hline \multicolumn{2}{|l|}{ SGPT, } \\
\hline \multirow{2}{*}{\multicolumn{2}{|c|}{ Feritin }} \\
\hline & \\
\hline \multicolumn{2}{|l|}{$\begin{array}{l}\text { Rerata } \pm \text { SB } \\
\text { CD4 absolut, }\end{array}$} \\
\hline $\begin{array}{l}\text { Median (kisaran) } \\
\text { CD4 (\%) }\end{array}$ & $706(393-1718)$ \\
\hline \multicolumn{2}{|l|}{$\begin{array}{l}\text { Rerata } \pm \text { SD } \\
\text { CD8 absolut }\end{array}$} \\
\hline \multirow{2}{*}{\multicolumn{2}{|c|}{ CD8(\%) }} \\
\hline & \\
\hline \multirow{2}{*}{\multicolumn{2}{|c|}{$\begin{array}{c}\text { Rerata } \pm \text { SB } \\
\text { Rasio CD } 4 / C D 8\end{array}$}} \\
\hline & \\
\hline Rerata $\pm \mathrm{SB}$ & $1,06 \pm 0,33$ \\
\hline
\end{tabular}

Keterangan: $\mathrm{n}=$ frekuensi, $\%=$ persentase, $\mathrm{SB}=$ simpang baku

absolut, CD4\%, CD8 absolut, CD8\%, dan rasio CD4/ CD8. Tabel 3 menunjukkan bahwa pada kelompok usia $\leq 5$ tahun, terdapat korelasi positif kadar feritin serum dengan CD8 absolut dan CD8\%. Terdapat korelasi negatif kadar feritin serum dengan rasio CD4/
Tabel 2. Korelasi kadar feritin dengan jumlah CD4 Absolut, CD4\%, CD8 Absolut, CD8\%, dan rasio CD4/CD8

\begin{tabular}{|c|c|c|}
\hline \multirow{2}{*}{ Variabel terikat } & Kadar feritin serum & \multirow[b]{2}{*}{$\mathrm{p}$} \\
\hline & Koefisien korelasi (r) & \\
\hline CD4 absolut & $-0,040$ & $0,417^{\mathrm{b}}$ \\
\hline CD4 \% & $-0,152$ & $0,211^{\mathrm{a}}$ \\
\hline CD8 absolut & 0,153 & $0,209^{\mathrm{b}}$ \\
\hline CD8 \% & 0,124 & $0,256^{\mathrm{a}}$ \\
\hline Rasio CD4/CD8 & $-0,249$ & $0,092^{\mathrm{a}}$ \\
\hline
\end{tabular}

Keterangan: analisis menggunakan korelasi aPearson, ${ }^{b}$ Rank Spearman, *bermakna bila $\mathrm{p}<0,05$

Tabel 3. Korelasi kadar feritin dengan jumlah CD4 Absolut, CD4\%, CD8 Absolut, CD8\%, dan rasio CD4/CD8 berdasarkan kelompok usia dan lama sakit

\begin{tabular}{|c|c|c|c|}
\hline \multirow{2}{*}{$\begin{array}{c}\text { Kelompok } \\
\text { usia } \\
\text { (tahun) }\end{array}$} & \multirow[b]{2}{*}{ Variabel terikat } & \multicolumn{2}{|c|}{ Kadar feritin serum } \\
\hline & & $\begin{array}{c}\text { Koefisien } \\
\text { korelasi (r) }\end{array}$ & $\mathrm{p}$ \\
\hline & CD4 absolut & 0,288 & $0,195^{\mathrm{a}}$ \\
\hline & CD4 \% & $-0,316$ & $0,172^{\mathrm{a}}$ \\
\hline$\leq 5$ & CD8 absolut & 0,691 & $0,009^{a *}$ \\
\hline & CD8 \% & 0,557 & $0,038^{\mathrm{a} *}$ \\
\hline & Rasio CD4/CD8 & $-0,680$ & $0,011^{\mathrm{a} *}$ \\
\hline & CD4 absolut & $-0,133$ & $0,293^{\mathrm{b}}$ \\
\hline & CD4 \% & $-0,081$ & $0,371^{\mathrm{a}}$ \\
\hline$>5$ & CD8 absolut & 0,023 & $0,463^{\mathrm{b}}$ \\
\hline & CD8 \% & $-0,053$ & $0,414^{\mathrm{a}}$ \\
\hline & Rasio CD4/CD8 & $-0,103$ & $0,337^{\mathrm{a}}$ \\
\hline \multicolumn{4}{|l|}{$\begin{array}{l}\text { Kelompok } \\
\text { lama sakit } \\
\text { (tahun) }\end{array}$} \\
\hline \multirow{5}{*}{$\leq 5$} & CD4 absolut & 0,230 & $0,224^{\mathrm{a}}$ \\
\hline & CD4 \% & $-0,424$ & $0,075^{\mathrm{a}}$ \\
\hline & CD8 absolut & 0,709 & $0,003^{a *}$ \\
\hline & CD8 \% & 0,571 & $0,021^{a *}$ \\
\hline & Rasio CD4/CD8 & $-0,726$ & $0,002^{\mathrm{a} *}$ \\
\hline \multirow{5}{*}{$>5$} & CD4 absolut & $-0,191$ & $0,231^{\mathrm{b}}$ \\
\hline & CD4 \% & $-0,031$ & $0,452^{\mathrm{a}}$ \\
\hline & CD8 absolut & $-0,020$ & $0,470^{\mathrm{b}}$ \\
\hline & CD8 \% & $-0,080$ & $0,380^{\mathrm{a}}$ \\
\hline & Rasio CD4/CD8 & $-0,062$ & $0,406^{\mathrm{a}}$ \\
\hline
\end{tabular}

Keterangan: analisis menggunakan Korelasi ${ }^{2}$ Pearson, 'Rank Spearman, *bermakna bila $\mathrm{p}<0,05$ 
CD8. Sementara pada kelompok lama terapi $\leq 5$ tahun, kadar feritin berkorelasi positif dengan CD8 absolut dan $\mathrm{CD} 8 \%$. Terdapat korelasi negatif dengan rasio CD4/CD8.

\section{Pembahasan}

Median usia adalah 6 tahun dari 30 subjek, jumlah anak laki-laki sama dengan perempuan, sebagian besar berstatus gizi baik, sudah didiagnosis sejak $>5$ tahun, interval transfusi darah setiap 4 minggu; semua subjek sudah mengalami kelebihan besi (kadar feritin $>1.000$ $\mathrm{ug} / \mathrm{nL}$ ), sudah mendapatkan kelasi besi (sebagian besar deferipron), kepatuhan konsumsi obatnya baik, serta kadar SGOT dan SGPT dalam batas normal.

Jumlah CD4 absolut, CD4\%, CD8 absolut, dan rasio CD4/CD8 menurun, sementara CD4 absolut, CD8 absolut dan CD8\% meningkat. Hal tersebut sesuai dengan hasil beberapa penelitian sebelumnya mengenai jumlah subset limfosit $\mathrm{T}$ pada penyandang talasemia mayor anak. ${ }^{5,9,15,20}$ Kadar feritin serum yang bertambah dapat menyebabkan kapasitas transferin (protein utama transpor besi) berkurang sehingga terbentuk non-transferrin bound iron (NTBI) yang terdapat dalam plasma dan labile iron pools (LIP) yang terdapat dalam sel sehingga kedua bentuk besi yang tidak terikat transferin ini membentuk hidroksi radikal bebas. Selanjutnya, kedua bentuk besi toksik tersebut akan merusak enzim pada lisosom dan menyebabkan kematian sel. Selain itu, akan mengakibatkan penurunan sistem imun sehingga berdampak pada pengurangan respons terhadap antigen dan fungsi limfosit T. ${ }^{16,20,24-27}$

Didapatkan kadar feritin dengan jumlah CD4, CD8, dan rasio CD4/CD8 tidak berkorelasi. Hal tersebut sama dengan penelitian sebelumnya yang melaporkan tidak ada korelasi kadar feritin dengan jumlah CD4, CD8, dan rasio CD4/CD8. Namun, kadar feritin ini berkaitan dengan fungsi dan kerja subset limfosit $\mathrm{T}$ dibanding dengan jumlah dan persentase subset limfosit $T .{ }^{16,21}$ Selain itu, kemungkinan karena heterogenitas secara klinis pada subjek penelitian dan perbedaan jumlah subset limfosit $\mathrm{T}$ pada etnis dan ras tertentu, serta usia subjek penelitian. ${ }^{17-19}$

Perubahan jumlah subset limfosit $T$ terjadi mulai usia $>5$ tahun. ${ }^{17-19}$ Pada penelitian ini didapatkan temuan berdasar atas usia $\leq 5$ tahun dan lama terapi $\leq 5$ tahun. Pada kelompok tersebut kadar feritin berkorelasi positif dengan CD8 absolut dan CD8\%, serta berkorelasi negatif dengan rasio CD4/CD8.

Hasil penelitian ini tidak dapat dibandingkan dengan penelitian sebelumnya karena belum ada yang melaporkan temuan berdasar atas usia $\leq 5$ tahun dan lama terapi $\leq 5$ tahun. Sementara pada kelompok usia $\geq 5$ tahun dan lama terapi $\geq 5$ tahun tidak ditemukan korelasi kadar feritin dengan CD4 absolut, CD4\%, CD8 absolut, CD8\%, dan rasio CD4/CD8. Penyebab hal ini tidak diketahui dengan pasti, kemungkinan karena pengaruh faktor ras, etnis, dan faktor-faktor yang perlu diteliti lebih lanjut pada penelitian selanjutnya. Perlu dilakukan penelitian lebih lanjut dengan ukuran sampel yang lebih besar untuk mengetahui korelasi feritin serum dengan subset limfosit T serum.

\section{Kesimpulan}

Tidak terdapat korelasi antara kadar feritin dengan jumlah CD4, CD8, rasio CD4/CD8. Peningkatan kadar feritin akan diikuti dengan peningkatan jumlah CD8 absolut dan CD8\%, serta penurunan rasio CD4/ CD8 pada penyandang talasemia mayor anak berdasar atas usia dan lama terapi $\leq 5$ tahun.

\section{Ucapan Terima Kasih}

Peneliti menyampaikan ucapan terima kasih kepada Guru Besar Departemen Ilmu Kesehatan Anak Fakultas Kedokteran Universitas Padjadjaran yang telah memberikan bimbingan selama penelitian ini berlangsung.

\section{Daftar pustaka}

1. Trachtenberg FL, Gerstenberger E, Xu Y, Mednick L, Sobota A, Ware H, dkk. Relationship among chelator adherence, change in chelators, and quality of life in thalassemia. Qual Life Res 2014;23:2277-88.

2. Caocci G. Health related quality of life in Middle Eastern children with beta-thalassemia. BMC Blood Disorders 2012;12:6

3. Galanello R, Origa R. Beta-thalassemia. Orphanet J Rare Dis 2010;5:11. 
4. Cappellini MD, Cohen A, Porter J, Taher A, Viprakasit V. Guidelines for the management of transfusion dependent thalassaemia (TDT). Cyprus: Thalassemia International Federation; 2014.

5. Hagag AA, Elgamasy MA, Elbar A. Assessment of T lymphocyte subsets in children with beta thalassemia major with iron overload. Egypt J Pediatr Allergy Immunol 2015;13:57-63.

6. Borgna-Pignatti C, Rugolotto S, De Stefano P, Del Vecchio GC, Forni GL, Gamberini MR, dkk. Survival and complications in patients with thalassemia major treated with transfusion and deferoxamine. Haematologica 2004;89:1187-93.

7. De Sousa M. Immune cell functions in iron overload. Clin Exp Immunol 1989;75:1-6.

8. Farmakis D, Giakoumis A, Polymeropoulo E, Aessopos A. Pathogenetic aspects of immune deficiency associated with $\beta$ thalassemia. Med Sci Monit 2003;9:RA19-22.

9. Vento S, Cainelli F, Cesario F. Infections and thalassaemia. Lancet Infect Dis 2006;6:226-33.

10. Sari TT, Gatot D, Akib AA, Bardosono S, Hadinegoro S, Harahap AR,. Idjradinata P. Immune response of thalassemia major patients in Indonesia with and without splenectomy. Acta Med Indones-Indones J Intern Med 2014;46:217-25.

11. Ricerca BM, Di Girolamo A, Rund D. Infections in thalassemia and hemoglobinopathies: focus on therapyrelated complications. Mediterr J Hematol Infect Dis 2009;1:e2009028.

12. Wanachiwanawin W. Infections in E-beta thalassemia. J Pediatr Hematol Oncol 2000;22:581-7.

13. Atasever B, Kuruca SE, Karakas Z, Agaoglu L. In vitro modulation of cellular immunity with antioxidants in patients with thalassemia major. Blood 2004;104:3775.

14. Walker EM Jr, Walker SM. Effects of iron overload on the immune system. Ann Clin Lab Sci 2000;30:354-65.

15. Kadam PP, Manglani MV, Sharma SM, Sharma RA, Setia MS. Immunoglobulin levels and CD4/CD8 counts in $\beta$ thalassemia major. Indian Pediatr 2014;51;1000-2.

16. Noulsri E, Lerdwana S, Fucharoen S, Pattanapanyasat K.
Phenotypic characterization of circulating CD4/CD8 T lymphocytes in $\beta$-thalassemia patients. Asian Pac J Allergy Immunol 2014;32:261-9.

17. Shahabuddin S, Al-Ayed I, Gad El-Rab M.O, Qureshi M I. Agerelated changes in blood lymphocyte subsets of Saudi Arabian healthy children. Clin Diagn Lab Immunol 1998;5:632-5.

18. Senju M, Makiyama K, Hara K, Hulstaert F, Lowder JN, Jewell DP. Two-color Immunofluorescence and flow cytometric analysis of peripheral blood lymphocyte subsets Caucasian and Japanese healthy subjects. Jpn J Med November- December 1991;30:509-11.

19. Tosato F, Bucciol G, Pantano G, Putti M.C,Sanzari M.C, Basso G, Plebani M. Lymphocytes subsets reference values in childhood. Cytometry Part A 2015;87:81-5.

20. Gharagozloo M, Bagherpour B, Tahanian M, Oreizy F, Amirghofran Z, Sadeghi HM, dkk. Premature senescence of T lymphocytes from patients with $\beta$ thalassemia major. Immunol Lett 2009;122:84-8.

21. Al-Awadhi AM, Alfadhli SM, Al-Khaldi D, Borhama M, Borusly M. Investigation of the distribution of lymphocyte subsets and zinc levels in multitransfused $\beta$-thalassemia major patients. Int J Lab Hematol 2010;32:191-6.

22. Ahmadiafshar A, Ghadipasha A, Mousavinasab N. Immunologic evaluation in patients with $\beta$-thalassemia major. Arch Dis Child 2012;97:A217.

23. Pourgheysari B, Karimi L, Beshkar P. Alteration of T cell subtypes in beta-thalassaemia major: impact of ferritin level. JCDR 2016;10:DC14-8.

24. Angelucci E, Arosi G, Gamaschella C, Capellini M, Cazzola M, Galanello R, dkk. Italian society of hematology practice guidelines for the management of iron overload in thalassemia major and related disorders. Haematologica 2008;93:741-50.

25. Andrews NC. Disorders of iron metabolism. N Engl J Med 1999;341:1986-95.

26. Kushner JP, Porter P, olivieri NF. Secondary iron over load. Hematology 2001;56:47-63.

27. Piperno A. Classification and diagnosis of iron overload. Haematologica 1998;83:447-55. 